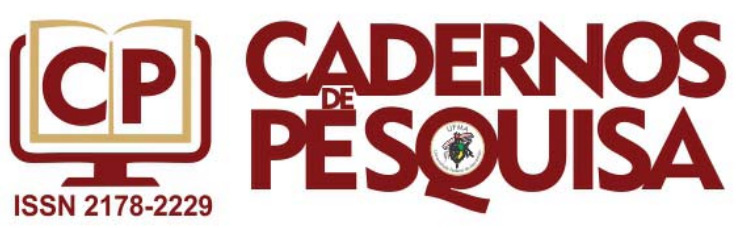

DOI: http://dx.doi.org/10.18764/2178-2229.v26n1p167-187

\title{
AS FORÇAS DO BRASIL COLONIAL E IMPERIAL QUE CONTRIBUÍRAM PARA A EMERGÊNCIA DO ENSINO DE QUÍMICA NA ESCOLA BRASILEIRA
}

\author{
THE FORCES OF COLONIAL AND IMPERIAL BRAZIL CONTRIBUTING TO THE \\ EMERGENCY OF CHEMISTRY EDUCATION IN THE BRAZILIAN SCHOOL
}

\section{LAS FUERZAS DEL BRASIL COLONIAL E IMPERIAL QUE CONTRIBUIRÁN PARA LA EMERGENCIA DE LA ENSEÑANZA DE QUÍMICA EN LA ESCUELA BRASILEÑA}

\author{
Fernanda Monteiro Rigue \\ Doutoranda em Educação pelo Programa de Pós-Graduação em Educação (PPGE) \\ da Universidade Federal de Santa Maria (UFSM). \\ Santa Maria - RS, Brasil. \\ fernanda_rigue@hotmail.com \\ Guilherme Carlos Corrêa \\ Professor Doutor do Curso de Licenciatura em Química \\ da Universidade Federal de Santa Maria (UFSM). \\ Santa Maria - RS, Brasil. \\ gcarloscorrea@gmail.com
}

\section{Resumo}

Busca-se, por meio de uma perspectiva genealógica (FOUCAULT, 1979), apresentar o jogo de forças que configura as estratégias para instauração das Ciências Naturais e a Química na Escola Nacional brasileira. A analítica aqui proposta segue a linha histórica da conformação de uma educação para todos pelo viés da formação de um campo epistemológico do Ensino de Química, perpassando pela Reforma da Universidade de Coimbra, os padres da Companhia de Jesus, Dom João VI, Dom Pedro I e Dom Pedro II no Brasil. O entrelaçamento dessas forças converge para emergência de uma Química, embora discreta, ao final do período imperial brasileiro.

Palavras-chave: Ensino de Química. Escola Nacional. Ciências Naturais. Genealogia.

\begin{abstract}
It is sought, through a genealogical perspective (FOUCAULT, 1979), to present the set of forces that configure the strategies for the establishment of the Natural Sciences and Chemistry in the Brazilian National School. The analysis proposed here follows the historical line of the formation of an education for all by the bias of the formation of an epistemological field of the Teaching of Chemistry, passing through the Reformation of the University of Coimbra, the priests of the Company of Jesus, Dom João VI, Dom Pedro I and Dom Pedro II in Brazil. The interweaving of these forces converges to the emergence of a chemistry, although discrete, at the end of the Brazilian imperial period.
\end{abstract}

Key words: Chemistry teaching. National School. Natural Sciences. Genealogy.

\section{Resumen}

Se busca, por medio de una perspectiva genealógica (FOUCAULT, 1979), presentar el juego de fuerzas que configura las estrategias para la instauración de las Ciencias Naturales y la Química en la Escuela Nacional brasileña. La analítica aquí propuesta sigue la línea histórica de la conformación de una educación para todos por el sesgo de la formación de un campo epistemológico de la Enseñanza de Química, pasando por la Reforma de la Universidad de Coimbra, los padres de la Compañía de Jesús, Mons. João VI, Don Pedro I y Pedro II en Brasil. El entrelazamiento de esas fuerzas converge para la emergencia de una Química, aunque discreta, al final del período imperial brasileño.

Palabras clave: Enseñanza de Química. Escuela Nacional. Ciencias Naturales. Genealogía.

Artigo recebido em setembro 2017. Aprovado em janeiro de 2019. 


\section{INTRODUÇÃO}

Para que o Ensino de Química se inserisse no contexto curricular da Escola Brasileira foi preciso o empenho de diversos esforços individuais e coletivos, desde a vinda dos primeiros padres da Companhia de Jesus, passando pelas iniciativas dos períodos Colonial e Imperial, o Estado Novo e o Desenvolvimentismo, até o final da Ditadura Militar. A emergência do Ensino de Química no Brasil constitui uma linha que inicia com pontos e segmentos esparsos e com poucas articulações entre si. Tais segmentos vão sendo alargados com consideráveis movimentos e forças.

É possível considerar que dois dos principais períodos que demarcam essas forças foram os períodos Colonial e Imperial, bem como alguns movimentos anteriores que impulsionaram as Ciências no Brasil. Se antes, na colônia, não havia interesse e condições estruturais para instalação de uma noção de 'educação' portuguesa, depois, com a expulsão da corte de Portugal, é preciso inaugurar no solo brasileiro uma nova concepção de mundo escolarizado, afirmada e integrada ao iluminismo Português.

A relação entre os períodos Colonial (1500-1822) e Imperial (1822-1889) só pode ser compreendida no Brasil pelo que representa a ruptura entre esses períodos. Ruptura conhecida como Reforma Pombalina, ocorrida em 1772, cujos aspectos se fizeram sentir primeiramente em Portugal, por meio das reformas ocorridas na Universidade de Coimbra, as quais também foram sentidas no Brasil nos anos seguintes. O estudo desses períodos envolve personagens e situações importantes apresentadas por diversas perspectivas históricas. Na medida em que foi possível ter contato com as obras responsáveis pela historicização desse processo, algumas tomaram destaque e serviram como referência ao presente estudo. Destacam-se: As ciências em Portugal e no Brasil (1772-1822): o texto conflituoso da química ${ }^{1}$, de Márcia Ferraz (1997); Marquês de Pombal: paradoxo do lluminismo², de Kenneth Maxwell (1996); Estórias da educação no Brasil: de Pombal a Passarinho3 ${ }^{3}$, de Lauro de Oliveira Lima (1969); Educação, comunicação, anarquia: procedências da sociedade de controle no Brasil ${ }^{4}$, de Guilherme Carlos Corrêa (2006).

A importância de ambos os períodos para a instauração do Ensino de Química na escola brasileira, através da Lei de Diretrizes e Bases para o Ensino de $1^{\circ}$ e $2^{\circ}$ Graus (LDBEN) n 5.692 de 1971, auge da Ditadura Militar, deve-se ao fato de introduzir a transposição de uma realidade europeia em um país de terceiro mundo. Inaugura-se uma visão de Ciência em um território outrora apenas ocupado por indígenas, negros e padres Jesuítas. É aqui que a catequese, o ordenamento religioso, os afazeres domésticos dão lugar ao aparecimento do naturalismo, laicos, na noção hegemônica de formação do cientista, da Ciência imperialista, da dependência nos modelos europeus (BAZIN, 1977) e de uma Química, embora discreta, voltada para a instrução pública e de controle do Estado no gerenciamento da educação.

Nesse sentido, o presente artigo trata de apresentar um panorama genealógico (FOUCAULT, 1979) do Ensino de Química nos períodos Colonial e Imperial, com base na análise das forças que concorreram para a emergência de uma Química, ao final de 1889, no Brasil. A Genealogia constrói uma espécie de linha que demarca as minúcias, descontinuidades e práticas específicas que condicionam o aparecimento de determinados acontecimentos e enunciados. É análise histórica que articula o corpo e a história, levando em conta os conceitos de proveniência e emergência. Proveniência como marca que estabelece uma espécie de linha pontilhada de iniciativas que contingenciam e põe em cena a emergência de determinadas forças. Forças que autorizam o aparecimento de práticas específicas, arquivos legais, discursos, entre outros.

\footnotetext{
Aborda a relação entre as reformulações da Universidade de Coimbra e seus resquícios no Brasil.

Versa sobre as principais ações e movimentos de Pombal no campo político, diplomático e científico em Portugal e no Brasil.

Apresenta um sobrevoo da Educação no Brasil, bem como as operações e articulações de Estado.

Discute quais esforços foram necessários empreender, que saberes foram promovidos, que jogos foram inventados para fazer da educação para todos esse bondoso e festivo direito que é, ao mesmo tempo, dura e incriminadora obrigatoriedade legal?
} 
Neste estudo, essas forças serão obtidas por meio de uma atenção para obras que permitem desenvolver um percurso histórico acerca da emergência de uma noção de Ensino de Química no Brasil. Logo,

a história, genealogicamente dirigida, não tem por fim reencontrar as raízes de nossa identidade, mas ao contrário, se obstinar em dissipá-la; ela não pretende demarcar o território único de onde viemos, essa primeira pátria a qual os metafísicos prometem que nós retornaremos; ela pretende fazer aparecer todas as descontinuidades que nos atravessam. (FOUCAULT, 1979, p. 35).

Assim, não interessa aqui a produção de respostas ou de uma 'nova' história ou 'verdade científica' da emergência do Ensino de Química no Brasil, mas a superfície dos acontecimentos e as potências do Ensino de Química como algo vinculado a diversas forças e iniciativas, sem que isso produza juízo de valor, para além do bem e do mal. A Genealogia atenta para as singularidades dispersas, em detrimento de uma busca pelas origens.

\section{O PERÍODO COLONIAL (1500-1822)}

\subsection{Marquês de Pombal: Reforma Pombalina e Estatutos da Universidade de Coimbra}

As Reformas na Universidade de Coimbra, impulsionadas pelos interesses e movimentos de transferência de uma química humoral com foco em uma medicina humoral, de Hipócrates e Galeno, para uma latroquímica e a ideia de saúde e doença, de Paracelso, formamproveniências interferentes no Brasil durante os períodos Colonial e Imperial.

A Reforma Pombalina, ocorrida em Portugal em 1772, teve como principal representante Sebastião José de Carvalho e Melo - conhecido como Marquês de Pombal. No seio dessa Reforma operou-se uma Reforma na Universidade de Coimbra, também em Portugal no referido ano. A Reforma, com novos estatutos promulgados, teve um papel bastante importante no aparecimento dainstrução das 'novas ciências' em Portugal. Essas reformulações foram marcadas por diversos Decretos e Estatutos, bem como pelos seus reflexos políticos, econômicos e sociais no território brasileiro após muito tempo, e que repercutiram na Independência do Brasil (1822).

O que moveu a Reforma no âmbito político-estratégico-militar esteve relacionado com a ascensão do humanismo; do interesse de Portugal em não mais depender da importação de subsídios exteriores e, desse modo, produzir, ali mesmo, a produção de alimentos; bem como em tornar a educação/ensino laica (desvinculada do cunho religioso). O lluminismo ${ }^{5}$ foi um estopim para a Reforma Pombalina, visto que as "ciências modernas" trouxeram críticas à atuação dos Jesuítas (então predominantes no ensino da época), principalmente através da figura de Marquês de Pombal. Pombal esteve envolvido em atividades nas embaixadas da Europa e foi nomeado ministro plenipotente de Negócios Estrangeiros e de Guerra pelo rei Dom José I, em 1750, sendo considerado como um antijesuíta, tendo em vista suas ações para a expulsão e extinção de quaisquer resquícios materiais e teóricos que fossem da Companhia de Jesus nesse território.

As ações do Marquês foram contrastadas com o contrassenso do iluminismo e do autoritarismo, no sentido que ele objetivou civilizar a nação através das ciências filosóficas, escravizando-a. Juntamente com "os melhores cérebros portugueses", o Marquês acompanhou e foi um eficiente concretizador, para que a Reforma Pombalina, incluindo a Reforma na Universidade de Coimbra, fosse instaurada em Portugal. Incansavelmente buscou alcançar as metas propostas e incitadas pela coroa Portuguesa,

\footnotetext{
Conhecido como século das Luzes, o movimento lluminista, com auge no final do século XVII, buscou extinguir as crenças e ideologias de cunho religioso. Questionava as "verdades" religiosas. O lluminismo teve como fundamento a presença do poder da razão do homem - 0 racionalismo presente nas Ciências. Autores como Kant (1724-1804), Rousseau (1712-1778) e Locke (1632-1704) preocuparam-se em divulgar os projetos intrincados no iluminismo, como fonte de progresso.
} 
sendo, uma delas, o interesse significativo pelo desenvolvimento e modernização do país.

Após suas iniciativas para a ascensão de Portugal, houve uma crescente crise em 1758. Segundo Maxwell (1996, p. 79), "a crise chegou ao seu ponto decisivo com a tentativa de regicídio em setembro de 1758", quando Dom José I (então braço direito e principal mandante das reformas) "regressava ao palácio após uma visita vespertina a sua amante, esposa do marquês Luís Bernardo de Távora, quando atiraram contra a sua carruagem" (MAXWELL, 1996, p. 79).

O rei foi ferido de modo suficientemente sério para que a rainha assumisse a regência durante a sua recuperação. Houve um silêncio oficial sobre o incidente até o início de dezembro, quando, numa grande operação de batidas policiais, muitas pessoas foram presas, inclusive um grupo de líderes aristocratas. (MAXWELL, 1996, p. 79).

Após essa ação, "as residências dos jesuítas foram postas sob guarda" ${ }^{6}$ procedeu-se a realização de interrogatórios, dos quais Pombal participou ativamente. Assim, "a 12 de Janeiro os prisioneiros foram sentenciados. Os crimes pelos quais foram condenados foram definidos como de lesa-majestade, traição e rebelião contra o rei e o Estado" (MAXWELL, 1996, p. 88). As condenações aos 'traidores' foram diversas: despedaçamento, decapitação e morte em fogueira. "No dia anterior à especular [espetacular?] punição dos aristocratas e dos demais condenados pelo atentado regicida, oito jesuítas foram presos por uma suposta cumplicidade entre eles e o Padre Gabriel Malagrida" (MAXWELL, 1996, p. 8). Conforme aponta Maxwell (1996), Pombal não mediu esforços para conseguir denunciar o Padre à Inquisição, lançando, em seguida, um alvará real afirmando que os jesuítas estavam em rebelião contra a coroa. Essa ação do Marquês reforçou o decreto de 21 de Julho de 1751, ordenando a prisão e expulsão de todos os Jesuítas do território brasileiro.

O Marquês usou a tentativa de assassinato de Dom José I como um meio para esmagar tanto a oposição aristocrática quanto os jesuítas em Portugal e no Brasil. Também utilizou a ocasião para atingir os pequenos comerciantes, que ele acusava de conspirar com os jesuítas contra seus planos, abolindo suas associações e, por conseguinte, sua representação ${ }^{7}$. A perseguição, seguida da abolição da ordem jesuítica, marca um conjunto imenso de reformas estendido a todas as esferas da administração, passando pela instrução, em todos os seus níveis, até a redefinição arquitetônica das obras públicas. Os documentos que dão ideia da magnitude da Reforma Pombalina são os Estatutos da Universidade de Coimbra (EUC).

No que se refere à criação dos estatutos,

\begin{abstract}
Para preparar os novos estatutos da universidade, criou-se a junta da Providência Literária em dezembro de 1770. O onipresente e maleável Dom João Cosme da Cunha era o presidente da junta e Francisco de Lemos tornou-se o reitor da reforma. João Pereira Ramos coordenou a parte jurídica em estreita colaboração com o marquês de Pombal, enquanto Francisco de Lemos concentrou-se nos novos estatutos relacionados com as ciências naturais e a matemática. (MAXWELL, 1996, p. 110).
\end{abstract}

Em1772, Dom José l8 promulgou Estatutos de Reformae renovação daUniversidade, reorganizando e renovando "a já existente Faculdade de Medicina" (PIRES; PEREIRA, 2010, p. 186) e criando as Faculdades de Filosofia e Matemática. "A de filosofia deveria incorporar não só as matérias tradicionais de metafísica, lógica e ética mas também as novas ciências naturais, que utilizavam a observação e a experimentação" (MAXWELL, 1996, p. 111). As cadeiras da Filosofia Natural constituíram-se de História Natural, Física Experimental e Química; às Ciências Naturais, desenvolvidas na Faculdade de Filosofia,

\footnotetext{
5 de Janeiro de 1757, BNLCP, Lisboa, códice 456, fo. 138 (fontes de arquivo).

Relatos e testemunhos desses processos podem ser visualizados detalhadamente em: Memórias de um jesuíta prisioneiro de Pombal de Anselmo Eckert, Lisboa, 1987; e História da expulsão da Companhia de Jesus da província de Portugal de José Caeiro, S. J., Lisboa, 1991.

8 Dom José I faleceu no ano de 1777 e a posição de Pombal logo se tornou insustentável (MAXWELL, 1996, p. 161).
} 
cabia produzir e formar pensadores consumados, dignos das luzes deste século, forte influência iluminista.

Os Estatutos apresentavam uma sequência de procedimentos os quais encadeavam as atividades e os anseiosda instrução das diferentes Ciências, expondo a complexidade crescente da elaboração do saberda ciência, além do "intuito de mudança do projeto pedagógico" (BOTO, 2011, p. 16). Para os seus idealizadores (grandes estadistas, secretários, bispos, juristas, médicos, intelectuais) era necessária a renovação de todo lastro intelectual e científico de modo a colocar Portugal como potência no cenário das navegações, do comércio e das nações colonizadoras onde destacavam França e Inglaterra. Segundo Boto (2011,

p. 15):

recuperar o atraso português significava, naquele tempo, transformar o estado das coisas em domínios públicos considerados estratégicos. Assim eram a Educação, a Justiça e a Medicina. Reformar os estudos universitários - bem como reformar a instrução das primeiras letras e secundária - era o passaporte para a Reforma de Estado; um Estado que se pretendia incluído em seu tempo, competitivo e potente.

Nesse mesmo sentido, argumenta Ferraz (1997, p. 42-43) que,

\begin{abstract}
no século XVII, a base dos estudos médicos na Universidade de Coimbra estava assentada na doutrina de Hipócrates e Galeno, a medicina humoral. Essa teoria pressupunha a doença como um desequilíbrio dos quatro humores (sangue, catarro, bílis amarela e bílis negra). O restabelecimento da saúde como a volta ao equilíbrio poderia ser alcançado ao se eliminar o que estava em excesso no corpo, principalmente por meio da sangria e da purga, provocadas pela utilização de medicamentos quase sempre de origem vegetal e animal. Os remédios eram ministrados notadamente na forma de decocções e de chás e também de destilados. Contrapondo-se a essas ideias sobre a saúde e a doença, Paracelso (1493-1541) defenderá a chamada iatroquímica, considerando a doença como de origem externa e localizada em partes do corpo. Isso tornará possível a ministração de medicamentos específicos de acordo com estado mórbido: tratava-se de restabelecer o funcionamento, por meio da ingestão de drogas, daquele órgão que se encontrasse com problemas. A preparação desses medicamentos privilegiava os materiais de origem mineral.
\end{abstract}

Têm-se aí os termos que promovem a passagem de uma doutrina Médica, principalmente Humoral, de Hipócrates e Galeno, para a latroquímica ${ }^{9}$ de Paracelso, enquanto Medicina externa. Nesse sentido, a Reforma denunciava o retardamento de um projeto de Educação em Portugal e apontava para uma renovação, segundo os moldes franceses e britânicos. Os estudos de Pires e Pereira (2010, p. 186) argumentam que, dentre os anseios, o foco principal da "[...] reforma pombalina foi a introdução da educação científica experimental no ensino universitário, em consonância com outras universidades europeias da época". Ao mesmo tempo para Serrão (1983, p. 163),

o triunfo das ideias iluministas, juntando-se à euforia do conhecimento científico, haveria de contribuir, nos fins do século XVIII, para a reforma do sistema universitário. A escola de tipo humanista, ainda que mantendo a estrutura medieval do ensino (Teologia, Leis Cânones, Medicina e Artes) fora-se abrindo cada vez mais às descobertas da Ciência, impondo as vantagens do saber utilitário em detrimento do labor puramente especulativo. Assim o exigia o progresso econômico e material dos Tempos Modernos, onde, a par do fortalecimento dos Estados, o homem ganhara uma nova perspectiva do real e que tinha de refletir-se ao nível de ensino. A Universidade surgia como peça de um sistema mais vasto que englobava todos os homens quanto à sua preparação intelectual e técnica.

Dentro desse mesmo aspecto, no contexto português "os novos Estatutos da Universidade de Coimbra (1772) têm na reforma dos estudos médicos provavelmente

A latroquímica é um coletivo de ideias que se preocupavam em explicar o funcionamento do corpo, juntamente com as doenças através de processos químicos.

Cad. Pesq., São Luís, v. 26, n. 1, p. 167-187, jan./mar., 2019. 
seu caráter mais emblemático" (BOTO, 2011, p. 19). A mudança do foco da Medicina Humoral para Medicina latroquímica precisava de uma base teórica assentada no solo português. Para tanto, foi necessária a mobilização de sua elite intelectual com o fim de validar, no cenário acadêmico, a nova orientação, por meio da publicação de obras científicas de referência.

Por meio da obra Traité de la virtudes médicamens, publicada em Paris, no ano de1739, Hermann Boerhaave afirmava que os corpos são formados por duas porções, uma sólida e outra fluida. Para ele "saúde depende de um movimento regular dos fluidos e, ao mesmo tempo, de uma resistência recíproca dos sólidos em todas as suas partes [do corpo]" (BOERHAAVE, 1739, p. 3-4). Nesse sentido, argumentava o EUC (1972, livro III, p. 182 apud FERRAZ, 1997, p. 46): "torna-se fácil compreender a preparação que os alunos deveriam ter para iniciar o curso médico propriamente dito: Geometria, História Natural, Cálculo, Física Experimental, Foronomia e Química, na Faculdade de Matemática e na Faculdade de Filosofica."

Essa sequência para compreender a preparação que os alunos deveriam ter mostra esse esforço em estabelecer as etapas de preparação do médico pela definição de etapas (níveis básicos) e sequência de conteúdos. Tornava-se clara a necessidade de um núcleo básico 'currículo mínimo'10 (conhecimento básico) para alcançar os núcleos superiores (conhecimento complexo). A série de reformas na referida universidade também incluía novos projetos arquitetônicos, dentre eles uma série de laboratórios de Ciências Naturais. A arquitetura passou a corresponder de modo mais evidente, à função das atividades próprias do fazer Químico. Segundo Crosland (2005), os laboratórios, onde se desenvolviam as atividades experimentais, deveriam ser espaçosos, isolados, bem equipados, ordenados, seguros, bem ventilados, possuir água encanada e fontes seguras de calor, "foi a introdução do espírito experimental nas aulas" (BOTO, 2011, p. 17).

"O novo currículo e a existência de laboratórios eram inovações excepcionalmente avançadas para a época” (CARVALHO, 1955 apud MAXWELL, 1996, p. 111). O laboratório Chimico é um dos edifícios reformados para marcar essa nova tendência da universidade reformada. A Química enquanto Ciência discreta, ou seja, como ciência separada/individualizada, não podia ser visualizada por completo nesse período, pois, nesse contexto, tinha pouca influência na base da formação dos médicos. Após a transferência da Medicina Humoral para a Medicina latroquímica, "a base da Matéria Médica assentava-se nos estudos da Química e também da História Natural quando se tratava de conhecer os produtos da Natureza, matéria-prima para a elaboração dos Medicamentos" (FERRAZ, 1997, p. 47). Além disso, no último ano do Curso Filosófico, a Química deveria deter-se em ensinar,

\footnotetext{
a separar differentes substancias, que entram na Composição de hum corpo; a examinar cada huma das suas partes; a indagar as propriedades, e analogias dellas; a compararllas, e combinarllas com outras substancias; e a produzir por mixturasdifferentemente combinadas novos compostos, de que na mesma Natureza não se acha modello, nem exemplo. (EUC apud FERRAZ, 1997, p. 49, sic.).
}

"A História Natural era, segundo os estatutos, a segunda cadeira do curso philosophico, e deveria servir de base à Física Experimental, a qual se seguiria depois a Chimica tanto teórica como practica" (PIRES; PEREIRA, 2010, p. 200). Essa função destinada às Ciências Naturais com ênfase na introdução de uma Química comportando-se enquanto ensino na formação de médicos (na terceira disciplina das Ciências Naturais) - assume uma atividade aplicada aos medicamentos e também a Farmácia, comportando-se como complemento necessário para sua existência e eficácia. Há uma mudança de perspectiva. "O médico, conhecendo a composição química dos materiais e a forma como seus componentes atuam mecanicamente no corpo humano, estaria capacitado para prescrever os medicamentos" (FERRAZ, 1997,

\footnotetext{
10 "Todos os currículos mínimos são mínimos de alguma profissão, de modo que os pais da Pátria funcionam como os gansos do Capitólio, evitando que alguém que trabalha sem o mínimo de habilitação, no país dos trabalhadores" (LIMA, 1969, p. 45).
} 
p. 49). Assim institui-se ao médico um poder de receitar, onde a universidade seria responsável por certificar a ele essa especificidade.

Quanto à modificação do modo de pensar as Ciências na referida Reforma,

a renovação da ciência compreendia averiguar novas dimensões dos variados campos do conhecimento. Havia de se traçar, para tanto, novas matérias de estudo. Porém, não se tratava apenas de inovar o domínio dos conteúdos. Era fundamental registrar também novas formas de ensinar, com o reforço do componente prático dos currículos. (BOTO, 2011, p. 15-16).

O professor de História Natural estaria encarregado de iniciar suas atividades por meio das 'lições', dando aos seus 'discípulos' uma ideia da Natureza e do globo terrestre em particular, limitando-os aos objetos mais vizinhos ao homem, e mais necessários ao uso da vida. Os objetivos, por trás desses indivíduos desbravadores da natureza, estariam interessados na descrição de cada um dos produtos/seres da natureza e no recolhimento da substância de todas as observações que sobre eles se tem feito.

As palavras 'lições' e 'discípulos', inerentes à função do professor de História Natural desse período, presentes nos Estatutos, trazem uma distinção ao modo como eram tratados no cunho religioso. As palavras lição e discípulo caracterizavam-se pela relação com os exercícios e problemáticas relacionadas com a passagem do ensino de cunho religioso para um ensino racional, técnico e científico. O que se apresenta, nos Estatutos, são noções e culturas de superioridade elencadas à função do professor como 'iluminador', sendo considerado capaz de disseminar seus conhecimentos aos alunos em torno das Ciências.

Os primeiros movimentos para instauração de uma noção de Educação das Ciências, com uma Química discreta, marcaram um espaço especial nas cadeiras de Filosofia Natural, na Reforma em Coimbra, tendo em vista a afirmação da necessidade de uma prática para o entendimento de conceitos teóricos nas cadeiras da Filosofia Natural. Como a Química não se incluía entre as disciplinas ensinadas em Portugal até o século XVIII, a Reforma exigiu a elaboração de novos métodos e formas para abordar a natureza, bem como a criação de espaços/momentos para discussões e estudos de metodologias, didáticas, conhecimentos da especificidade da área, sendo eles: o Gabinete de História Natural, o Jardim Botânico, o Gabinete de Física Experimental e o Laboratório Químico.

Em suas reformas econômicas, Pombal sempre se defrontou com o problema da limitada capacidade empresarial de Portugal. Não menos crucial era o problema de encontrar indivíduos convenientemente qualificados para levantar avante a transformação das estruturas educacionais e administrativas do país. A criação do capital humano era na verdade um processo mais lento do que o de acumular riquezas pela manipulação de tarifas ou da concessão de monopólios lucrativos. (MAXWELL, 1996, p. 114).

Nesse cenário, existia uma vasta dificuldade em encontrar habilitados na área das Ciências Naturais/Química em Portugal, o que acarretou a busca de profissionais "de mentalidade moderna" (MAXWELL, 1996, p. 114) em outros países da Europa, para suprir a falta de aptos a desenvolver ações/pesquisas, após as medidas planejadas e empregadas. Decisões políticas instituíram modificações no cenário educacional vigente. Segundo Filgueiras (1998, v. 8) por falta de especialistas em Portugal, Pombal orientou que buscasse, [na região de Pádua] na Itália, o professor Domingos Vandelli, a quem coube estabelecer a cátedra de Química na universidade.

As características de Vandelli em torno das Ciências Naturais eram muito mais naturalistas e iluministas, do que Químicas propriamente aplicadas. Além das suas atividades didáticas, ele se dedicou, por um longo período, à manufatura de louça que ficou conhecida com o seu nome, após ter realizado, no Laboratório Químico, os testes primeiros para a fundação da fábrica. Vandelli também foi responsável pela formação 
de muitos Brasileiros que, oriundos do Brasil, prosseguiram os estudos nas Ciências Naturais no solo Português, tendo em vista a inexistência de formação acadêmica no Brasil. Filho do primeiro professor de Química de Coimbra, Vandelli era Químico português.

Vandelli era um recorrente ao uso da experimentação nas suas práticas pedagógicas, visto que apresentava um interesse concreto em preparar os estudantes para a carreira de Medicina e instruídos estudantes de Farmácia. Sua forte relação com Economia tinha intuito de fazer com que as Ciências Naturais deixassem de ser encorajadas apenas pela curiosidade e pelo divertimento dos então "curiosos cientistas pesquisadores", mas sim pela necessidade de crescimento e progresso desenvolvimentalista da nação. Foi ele quem propôs a criação das cadeiras envolvendo a Química e História Natural em Lisboa, bem como as viagens filosóficas, realizadas por naturalistas, para catalogação de plantas e substâncias naturais nas colônias. Ademais, pensava que para a Faculdade de Filosofia Natural alcançar reconhecimento no cenário nacional e internacional, era fundamental que seus professores tivessem renome, assim como os demais de outras universidades da Europa (França e Inglaterra). Além disso, os alunos egressos deveriam ter cargos destinados a todas as áreas de atuação. Sendo assim, foi destaque responsável pela formação de naturalistas com forte pendor nas Ciências Naturais e, a ocupação de cargos político-estratégico-militares no país.

Os estudos de Ferraz (1997) apontam que José Bonifácio de Andrada e Silva11, que também fora um forte representante político no Brasil, junto a Dom Pedro I, após o envolvimento com o naturalismo, fora aluno de Vandelli. Nesse contexto, é interessante perceber a forte ligação entre as Ciências Naturais da época frente à ocupação de cargos de liderança e políticos na Europa e também no Brasil. Os 'grandes nomes' do meio acadêmico desempenhavam e apropriavam-se de outras esferas e cargos políticosmilitares na sociedade civil, observando-se e consolidando-se o sucesso prometido por trás das propagandas científicas e o progresso dos conhecedores de seus conceitos e normas.

Conforme Filgueiras (1998, v. 8), José Bonifácio viajou por diversos anos pela Europa, participando de aulas e estágios industriais em mineralogia, mineração e metalurgia. Seus trabalhos estavam relacionados também com a Química, visto que catalogou minerais e várias espécies ainda não conhecidas de minerais. Esteve muito mais preocupado em pensar e apresentar um método de análise de fácil compreensão do que denominar e classificar as substâncias. Ainda para Filgueiras (2015, p. 186) José Bonifácio destacou-se também na fotoquímica "veio, por seus estudos na área, a tornar-se um pioneiro na fotoquímica. Não se deve esquecer o contexto da época, em que a química orgânica estava em sua infância, naquele início do século XIX". "Estudou em Coimbra e permaneceu na Europa entre 1783 e 1819" (FAUSTO, 2001, p. 73). Teve uma carreira longa e multiforme, já que, antes da carreira política no Brasil, fora um pesquisador em Portugal até completar seus cinquenta e seis anos de idade.

\footnotetext{
Uma vez de volta, José Bonifácio passou a acumular uma série de encargos que, embora Ihe tomassem um tempo precioso de seus afazeres científicos e acadêmicos, foram inestimáveis em um novo tipo de treinamento, a política e a administração pública, que mais tarde vieram a ter enorme importância, sobretudo em sua fase brasileira na época da independência. Ele veio a ser intendente-geral das Minas e Metais do Reino, membro do Tribunal das Minas, diretor do Laboratório Químico da Casa da Moeda, administrador das Minas de Carvão de Buarcos e das Fundições de Ferro de Figueiró dos Vinhos e Avelar, entre várias outras atribuições. (FILGUEIRAS, 2015, p. 184).
}

No Brasil, José Bonifácio exerceu a função de preceptor do Príncipe Dom Pedro I, influindo nos destinos do país. Além de Bonifácio, Vicente Coelho de Seabra da Silva Telles (1764-1804) foi um dos brasileiros que também se dedicou à estudar Ciências da natureza, sendo autor do primeiro livro em português fundamentado na "nova química

11 José Bonifácio nasceu no ano de 1763, em Santos - Brasil. 
moderna" de Lavoisier (1751-1794) conhecido como "Elementos de química", publicado em 1788. Igualmente, Alexandre Rodrigues Ferreira e João da Silva Feijó foram indicados por Vandelli para atuarem na cadeira de História Natural e Demonstrações Químicas no Museu de História Natural, Jardim Botânico e Laboratório Químico na Ajuda.

O Curso Filosófico, estabelecido por meio das iniciativas da Reforma Pombalina, obrigatório em Coimbra aos futuros estudantes de diversas faculdades, podia conferir o grau de bacharel e de doutor em Filosofia Natural, sendo necessário pagar algumas taxas, graduando-se o chamado naturalista. A ele estaria destinado o cargo direcionado para a atividade de coleta, descrição e análise de plantas de diversas espécies. $O$ naturalista, chamado também de Filósofo Natural, passa a ser um desbravador das riquezas da coroa portuguesa nas colônias do 'novo mundo'. Os naturalistas, muito mais do que envolvidos com pesquisas academistas, estavam estritamente envolvidos com a Academia Real de Ciência e o Laboratório Químico da Moeda no Brasil. Do mesmo modo, é íntimo o interesse econômico na retaguarda das iniciativas inovadoras das Ciências Naturais nesse período, isso porque as viagens de reconhecimento eram indispensáveis para as decisões adequadas aos produtos e focos de exploração no conhecido Novo Mundo (Américas).

É nesse cenário que a Universidade da cidade de Coimbra e a Academia Real de Ciências de Lisboa (fundada em 1779) estavam estritamente preocupadas com a formação dos naturalistas, os quais deveriam ser encarregados de realizar viagens exploratórias até as colônias de Portugal, coletando matérias primas e informação 'secretas e sigilosas' para o reino português. O objetivo central dessa reforma esteve diretamente ligado ao interesse de ascensão de Portugal em meio à Europa, objetivando fugir da dependência alimentícia, têxtil e financeira dos demais países do continente. Por isso, modernizar a educação como um meio para alcançar tais finalidades.

Ambas Reformas ocorridas em Portugal, impulsionaram a ida de Pombal, em 1759, para o solo da colônia portuguesa, no Brasil, para tentar extinguir, assim como foi em Portugal, os resquícios dos Jesuítas (representantes da religiosidade), principalmente dos padres da Companhia de Jesus, bem como suas iniciativas de cunho político e de caráter educacional. Nesse contexto, os estudos de Maxwell (1996, p. 168) afirmam que "o papel da reconstrução intelectual é, portanto, algo que somos obrigados a levar em conta para compreender Pombal e Portugal do século XVIII."

O que veio para o Brasil é resultado dessa mudança fortalecida pelo lluminismo corrente. A noção de natureza se transforma e Deus deixa de ser o senhor da Natureza, mas sim o homem - a racionalidade. Com essa passagem da Medicina para as Ciências Naturais e Filosóficas em Coimbra, a Reforma do Marquês põe em prática os preceitos iluministas. Existia uma tentativa explícita de pensar estratégias para a instauração de uma nova tradição em solo 'aparentemente' não povoado ${ }^{12}$, alicerçando e facilitando a adequação e o esvaziamento de possíveis culturas e tradições situadas nesse território. Segundo eles, o intento era levar cultura, ciência e história para um lugar e uma gente desprovida, segundo o modo de ver colonizador de tudo isso.

\subsection{Pombal no Brasil: nem Escolas, nem Ciências}

A Educação Brasileira, no Período Colonial (1500 - 1889), está diretamente relacionada às missões jesuíticas, em especial aos padres da Companhia de Jesus ${ }^{13}$. A Companhia de Jesus atuou no Brasil entre 1549 até 1759. Suas disposições no território nacional se concentravam no litoral e no interior. No litoral, os jesuítas eram oriundos do solo português e, no interior, eram da Espanha. No litoral os jesuítas preocuparam-se em fundar colégios e, no interior, com a chegada posterior, houve uma preocupação na instalação de reduções, através de um projeto de sociedade.

\footnotetext{
${ }_{12}$ É importante ressaltar que nesse período o solo brasileiro era ocupado por índios.

13 A Companhia de Jesus teve como fundador Inácio de Loyola (1491-1556). Teve reconhecimento como ordem religiosa pelo Papa Paulo III, no ano de 1540. Segundo Nunes (1980, p. 108), a criação dos colégios pela Companhia de Jesus era indispensável. "[...] para a renovação cristã da Europa e para a extensão do reino de Deus nas terras de missão". A Companhia de Jesus criou uma organização/método educativo, conhecido como Radio Studiorum que organizou o funcionamento dos colégios.
} 
Com anseio de refutar os incrédulos, perpetuar a fé e impedir a crescente do Protestantismo, os sacerdotes da Companhia ficaram encarregados, durante mais de 200 anos, de catequizar o Novo Mundo, a colônia. Conforme Corrêa (2000, p. 52), "o grande esforço dos jesuítas para cristianizar os índios por meio da persuasão iniciou pela reunião dos nativos em grandes promoções místicas nas quais realizavam a missa e batizavam um grande número deles tornando-os filhos de Deus."

Durante os 200 anos em que os sacerdotes da Companhia de Jesus permaneceram no Brasil, foram referência de Educação. Empregavam uma estratégia de comunicação para utilizar recursos lógico-racionais, induzindo o aceitamento das ideias por parte dos índios (nativos) que aqui viviam. Segundo Filgueiras (2015, p. 49) "além da defesa intransigente da ortodoxia, sobretudo em face das novas heresias protestantes, a Companhia de Jesus se destacou nas atividades de ensino em todos os níveis." Do mesmo modo, Lauro de Oliveira Lima (1969, p. 24) afirma que "os padres, em seu idealismo meio alienado, por vezes, extrapolam sua função "humanizante", esquecendo que as verdadeiras soluções não estão neste vale de lágrimas."

\begin{abstract}
os jesuítas assentam, logo ao desembarcar, os seus arraiais; fundam suas residências ou conventos, a que chamavam - "colégios", estalam os seus centros de ação e de abastecimentos, ou, se o quiserem, os seus quartéis, para a conquista e o domínio das almas, penetram as aldeias dos índios e, multiplicando, ao longo da costa, os seus pontos de irradiação, estabelecem-se, ao sul, sob a inspiração luminosa do Pe. Manuel de Nóbrega, na Capitania de São Vicente, em que reconhecem - "a porta e o caminho mais certo e seguro para as entradas ao sertão." (AZEVEDO, 1963, p. 501).
\end{abstract}

A criação de aldeamentos possibilitou um maior controle das ações, pensamentos, características e peculiaridades dos índios (principalmente crianças), levando os antigos libertos e instintivos a uma vida recheada de normativas, diretrizes adequadas à moral e à instrução. A adição de noções morais anexou à punição na administração das aldeias, que poderiam ser exercidas tanto por funcionários da coroa (políticos, administradores, sacerdotes), quanto por meirinhos (Oficiais de Justiça da época). Suas iniciativas foram tão triunfais que possibilitaram o planejamento e a criação dos colégios, sendo os meninos os únicos autorizados a frequentá-los. "O que parece certo é que os alunos externos ou seculares do Colégio dos jesuítas estavam submetidos, senão a um serviço militar, ao menos aos deveres iguais aos de uma milícia" (ALMEIDA, 2000, p. 29).

Era nesse espaço que os corpos eram moldados, corrigidos e padronizados, buscando retirar a tendência animalesca daqueles indivíduos (os índios). Tratava-se de uma Educação de Ordem Religiosa e os professores (padre/sacerdote) incorporavam a figura superior do professor, provocando a própria renúncia de si. Segundo as lentes de Corrêa (2000), surgiu, nesse contexto, a figura de professor-padre, do formador de almas.

Conforme os novos continentes foram sendo 'descobertos', por meio das grandes navegações, a Educação (assim como as demais estruturas sociais) de cunho religioso, que anterior às navegações estava baseada exclusivamente nas letras e na retórica, passou a preocupar-se com áreas diversas (Matemática e as Ciências Naturais), as quais tinham forte influência e respaldo nas atividades econômicas e mercantis realizadas pelas potências colonizadoras, nas suas maiorias europeias.

Os jesuítas logo fundaram seu primeiro colégio em Salvador, onde vieram a implantar seu código pedagógico, a Ratiostudiorum. O curso dado aos alunos abrangia desde as primeiras letras até as Faculdades de Letras, Artes e Teologia. No curso de Letras estudavam-se todos os clássicos. No Brasil, não se estudava o grego, que foi substituído pelo chamado grego da terra, a língua dos índios, de que Anchieta viria a escrever a primeira gramática. No curso de Artes ou Ciências Naturais ensinavam-se a lógica, a física, a metafísica, a ética e a matemática. (FILGUEIRAS, 2015, p. 49). 
Sobre o método pedagógico adotado pelos Jesuítas - RatioStudiorum - pode-se dar destaque a presença de pressupostos filosóficos e teológicos que visavam manter os saberes do ensino medieval.

\begin{abstract}
O curso de Filosofia e de Ciências, também chamado de Artes e dividido em três anos, tinha por fim a formação do filósofo pelos estudos de lógica, metafísica geral, matemáticas elementares e superiores, ética, teodicéia e das ciências físicas e naturais, tomadas pela escolástica e estudas ainda a esse tempo como - "ciências constituídas definitivamente pelas especulações aristotélicas". Em Aristóteles, segundo os escolásticos, estava tudo: nada que investigar ou que discutir; só havia que comentar. (AZEVEDO, 1963, p. 519).
\end{abstract}

Com frequência, nas aulas de retórica, os alunos participavam de acirrados momentos de disputa. Disputatio era o momento em que os estudantes confrontavam (através de declamação) posição quanto a um tema ou assunto selecionado ou definido anteriormente. Premiações eram dadas aos estudantes que se saiam bem nas disputas. Aqui, a estratégia era fixar o que foi desenvolvido, por meio de disputa. "A aula era dividida em dois campos, romanos e cartaginenses, cada qual com o seu estandarte; em cada campo dispunham-se por ordem de merecimento os diferentes graus" (FRANCA, 1952, p. 38-39).

No que diz respeito à descrição da natureza brasileira (fauna, flora, etc.) e das técnicas Químicas utilizadas no período jesuítico, Filgueiras $(2015$, p. 61) afirma que os "séculos XVI e XVII são muito ricos em relatos da natureza brasileira e de muitas técnicas desenvolvidas aqui ou trazidas de fora, assim como riquíssimas e pormenorizadas descrições da natureza brasileira."

Antes da vinda da Família Real para o Brasil, as iniciativas dos Jesuítas eram as únicas referências de Educação reconhecidas no território brasileiro "os jesuítas concentraram em suas mãos o ensino da mocidade, fossem seus tutelados filhos de portugueses, índios ou mestiços" (FILGUEIRAS, 2015, p. 49). Muitos foram os esforços para instalação de Universidades de Ensino Superior no solo da colônia brasileira, porém eram negadas todas as propostas de criação, visto que a Universidade de Coimbra não havia possibilitado que as instituições de ensino (colégios) se tornassem universidades. "Não havia, pois, na Colônia estudos superiores universitários, a não ser para o clero regular ou secular, este formado em Coimbra ou pelos jesuítas na Colônia, sobretudo no século XVIII" (AZEVEDO, 1963, p. 524).

Conforme afirma Lima (1969, p. 55), "nos tempos coloniais não havia entre nós biblioteca pública de natureza alguma; possuíam, porém, os conventos, riquíssimas livrarias, de uso exclusivo dos religiosos, onde nenhum profano ousava entrar." Segundo Filgueiras (2015, p. 52), mesmo que poucas evidências sejam possíveis, "percebe-se que possivelmente algum ensino científico haveria nas instituições jesuítas ou, pelo menos, seria acessível, a quem se interessasse, dispor dos meios necessários ao estudo."

Em 1759, existiam apenas alguns colégios, restritos seminários e internatos no Brasil. Nos colégios, permitia-se,

\footnotetext{
[...] educar os meninos em espaços fechados, por selecionar saberes tidos como universais, por reunir estes saberes em programas com dificuldades crescentes adequados às capacidades infantis e submetidos a censuras morais, a escola jesuítica lançou as bases sobre as quais sustenta-se, até hoje, o nosso sistema de educação escolar. (CORREAA, 2000, p. 58).
}

No mesmo ano, o Marquês, através da sua vinda ao solo da colônia, expulsa os Jesuítas e os Padres da Companhia de Jesus do solo brasileiro, dando espaço para a formalização de Aulas Régias. "Não foi um sistema ou tipo pedagógico que se transformou ou se substituiu por outro, mas uma organização escolar que se extinguiu 
sem que essa destruição fosse acompanhada de medidas imediatas" (AZEVEDO, 1963, p. 539 apud LIMA, 1969, p. 23).

A iniciativa mais marcante de Pombal, agora no Brasil, esteve relacionada com à criação das Aulas Régias, em que ele objetivou, após a expulsão dos Jesuítas ${ }^{14}$, a construção de subsídios literários ditos ainda não explorados pelos padres da Companhia de Jesus. A publicação de um Alvará Régio, em 1759, extinguiu quaisquer que fossem os resquícios das escolas dos jesuítas, tanto em Portugal quanto em suas colônias, dando espaço para o Latim, o Grego, a Filosofia e a Retórica. Há aqui o esforço inicial de fragmentação do ensino, com as primeiras disciplinas distintas uma das outras.

Entre 1771 e 1772 foi criada a Academia Científica do Rio de Janeiro (RJ), que constituía a mobilização para a série de reformas que seriam realizadas agora no solo da antiga colônia. Para isso, a Coroa precisou tomar algumas medidas, em 1772, "foi criado um imposto especial - o subsídio literário - para sustentar o ensino promovido pelo Estado. O bispo de Pernambuco criou o seminário de Olinda, que se voltou em parte para as ciências naturais" (FAUSTO, 2001, p. 61).

A passagem de uma educação promovida pelos Jesuítas para as Aulas Régias era entendida por Pombal como a substituição do arcaico pelo novo, do obscuro pelo iluminado. Fundar o cargo de Diretor Geral dos Estudos inaugurou a dependência do educar nas mãos do Estado, uma vez que esse cargo tinha como finalidade realizar a fiscalização dos professores e a sua contratação. Pombal foi o primeiro a sustentar e dar ênfase a ideia de que, ao criar um curso de Direito, nomeando um diretor, poderia ser criada uma Universidade. Em contrapartida, como não havia educadores formados naquela época, esse foi um período de desordem na educação do solo brasileiro. Segundo Lima (1969, p. 27),

durante os 130 (cento e trinta) anos seguintes (de 1759 a 1889), a educação nacional ficou sem uma "companhia" órgão público ou associação religiosa encarregada de promovê-la: nenhum órgão público ou religioso tinha, neste período, como objetivo promover a educação geral da população (por sinal, predominantemente, escrava).

A partir da Reforma de Pombal, iniciada em 1772, juntamente com o aparecimento das Ciências experimentais, brasileiros procuraram deslocarem-se para Portugal, visando graduarem-se em carreira científica ou médica ${ }^{15}$. Marquês de Pombal, juntamente com os considerados melhores cérebros de Portugal, preocupara-se em expulsar os resquícios de catequização empregada pelos Jesuítas, dando corpo às Luzes eminentes em Portugal, por meio da instalação das Ciências Modernas. Poucas contribuições ofereceram abalar o edifício solidificado do analfabetismo. Além de Portugal proceder com extrema "sovinice" no pagamento dos professores, os recursos do "subsídio literário" eram desviados e nem sempre foram aplicados na manutenção de uma rede escolar (CARRATO, 1973, p. 148-151 apud LIMA, 1969, p. 24).

Pode-se considerar que Pombal articulou que,

é preciso estabelecer primeiro o plano de educação e instrução pública, o ensino dos estudos menores, para então ter lugar o estabelecimento de colégios e universidades onde se ensinassem as ciências maiores, mas reconhece ser justo que um não espere o outro e que para melhor aproveitamento desde já se estabelecessem as universidades, que pela forma atual de seus estudos pudessem dedicar-se os aos maiores. (LIMA, 1969, p. 78).

As aulas régias pensadas e articuladas por Pombal, segundo Lima (1969, p. 24) "[...] nem de longe representavam um 'sistema', assim como não se podia chamar de 'educação' as mirradas escolinhas de ler, escrever e contar." Sobre esse aspecto, em especial sobre escolas superiores, o autor também discorre que:

\footnotetext{
$\overline{14}$ Segundo Lima (1969, p. 84), foram 590 padres expulsos e 19 encarcerados até 1777.

15 Segundo Filgueiras (2015, p. 75), "no Brasil colonial, a escassez de médicos era notória. O tratamento de doentes muitas vezes ficava a cargo dos conventos, dentre os quais se destacaram os jesuítas. Suas boticas possuíam cada qual seu conjunto de preparações e fórmulas."
} 
as escolas "superiores" do Império era, apenas, um tipo de "dramatização" para dar à feitoria ar provisório de corte, solução muito parecida com a do administrador contemporâneo que sugeriu pintar as favelas de arco-íris... nas épocas de carnaval, para subtraí-las à curiosidade dos turistas bisbilhoteiros. Pombal não destruiu, propriamente, um sistema escolar, simplesmente, porque sistema escolar não existia. O Brasil era uma espécie de "cais do porto", uma feitoria de onde se extraíam matériasprimas [...] O fato é que Pombal destroçou o frágil e monacal "sistema" que os padres jesuítas vinham montando em trezentos anos de esforço para ensinar o latim aos mamelucos. (LIMA, 1969, p. 24).

A preocupação de Pombal e a vinda da Família Real para o Brasil levaram à criação e à efetivação de vários Alvarás, Resoluções, Legislações e outros importantes documentos para as Ciências no Brasil. Antes da vinda da Corte da Família Real para o território brasileiro, os portugueses apenas vinham para a então Colônia (Brasil) com a finalidade de produzir riquezas e extrair matéria prima, o que justificava uma estada provisória.

Sabendo disso, é importante pontuar que Pombal morreu no ano de 1872, cinco anos após sua queda (MAXWELL, 1996). De modo geral considera-se que o período Colonialtratou-se de uma época muito nebulosa no território brasileiro. Foi uma primeira tentativa para instalação de uma educação com forte dependência no Estado, por meio da tentativa de secularização do ensino a partir das Aulas Régias. A expulsão dos padres da Companhia de Jesus representou um desmantelamento no que se refere à educação existente na época. No período Colonial brasileiro, ainda não há resquícios, de um Ensino da Química ${ }^{16}$ estruturado, sendo essa ciência, uma ciência discreta, resignada apenas aos Jardins e Museus, servindo de apêndice para Medicina.

\title{
2.3 A vinda e a instalação da Família Real no Brasil e as iniciativas de Dom João VI (1808) - Formalização de espaços científicos
}

Em 1808, a Família Real portuguesa transferiu-se para a antiga colônia (o território brasileiro). Nesse período, a colônia vivia um intervalo de reconhecimento territorial e de vasta exploração mineral. Conforme Lima (1969, p. 54), "a cobiça de outras potências pelas terras quase abandonadas na América e o declínio da atividade lusitana no Oriente - levariam a administração portuguesa a incrementar a ocupação definitiva do nosso país." Segundo Ferraz (1997), a transferência da Família Real para a antiga colônia brasileira aconteceu repentinamente, induzindo muitas pessoas e conhecimentos oriundos de Portugal fossem transferidos para o território colonial, antes apenas explorado (pau-brasil, minérios, plantas, etc.). Conforme Lima (1969, p. 19),

\begin{abstract}
até 0 ano de 1808, ocasião em que chegou à Colônia a Família Real Portuguesa, escorraçada da Europa por Napoleão, herdeiro da Revolução Francesa, eram proibidos, no Brasil, escolas, jornais, circulação de livros, associações, discussão de idéias, bibliotecas, fábricas, agremiações políticas e qualquer outra forma de movimento cultural ou de produção livre de bens, sendo as opiniões controladas pela moribunda, mas eficiente, inquisição Peninsular que veio atuar também no Brasil e daqui jamais se mudou (o primeiro jornal "brasileiro" circulou em Londres).
\end{abstract}

Para Fausto (2001, p. 69) "a vinda da família real deslocou definitivamente o eixo da vida administrativa da Colônia para o Rio de Janeiro, mudando também a fisionomia das cidades." Essa vinda trouxe para o Brasil a ascensão das instituições superiores, através do estabelecimento de uma Carta Régia no dia 18 de fevereiro de 1808. Houve a criação das primeiras Cadeiras de Cirurgia e Anatomia na Bahia e na cidade do Rio, e da Engenharia na Academia Real Militar em 1810.

Em relação à abertura de espaços para a continuidade dos anseios portugueses, agora no Brasil, verifica-se que,

${ }^{6}$ Segundo Filgueiras $(1998, v .8)$, no ano de 1772, houve o primeiro livro a ter no título a palavra Química. De autoria Manoel Joaquim Henriques de Paiva, teve-se: Elementos de Química e Farmácia.

Cad. Pesq., São Luís, v. 26, n. 1, p. 167-187, jan./mar., 2019. 
em setembro de 1808 veio a público o primeiro jornal editado na Colônia; abriramse também teatros, bibliotecas, academias literárias e científicas para atender aos requisitos da Corte e de uma população urbana em rápida expansão. Basta dizer que, durante o período de permanência de Dom João VI no Brasil, o número de habitantes da capital dobrou, passando de cerca de 50 mil a 100 mil pessoas. (FAUSTO, 2001, p. 69).

Dentre as ações de Dom João VI, no Brasil, a principal esteve relacionada com a abertura dos portos para as nações amigas, realizada no dia 28 de Janeiro do ano de 1808, a qual marcava uma ação diplomática para ascender as relações internacionais. Almeida (2000, p. 55) afirma que abrir os portos "canalizou para o Brasil uma corrente de imigração, fraca em número, é verdade, mas considerável pelo mérito e pelo saber." Ainda, conforme Filgueiras (2015, p. 197),

\begin{abstract}
dentre as medidas iniciais mais importantes tomadas por D. João estão a abertura dos portos no Brasil, cessando o isolamento do país em relação ao mundo não português, e a criação da Escola de Anatomia e Cirurgia da Bahia, ambas em fevereiro de 1808, durante a escala de um mês que fez em Salvador, ao vir de Portugal. Pouco depois ocorreria a criação de uma escola análoga em seu destino final, o Rio de Janeiro, em abril do mesmo ano, a Escola Anatômica, Cirúrgica e Médica. As mudanças continuaram com a fundação do Real Horto, mais tarde Jardim Botânico, destinado à aclimatação de plantas exóticas e de eventual interesse econômico, e da Impressão Régia, mais tarde Imprensa Nacional, que acabou com a velha proibição de se imprimirem livros no Brasil.
\end{abstract}

As obras dos seguintes autores consultados: Mathias (1979), Almeida (2000), Fausto (2001) e Filgueiras (2015), tratam do ato de abrir os portos por Dom João VI como um ponto totalmente favorável para a ascensão do Brasil e, principalmente, para os setores do comércio e da economia. Todavia, não se preocupam em argumentar e tencionar sobre o quanto de minérios e matéria-prima foram furtados do território nacional e levados para a Europa, com intuito de quitar as dívidas da metrópole portuguesa. Mercúrio, ferro, chumbo, ouro, cobre, madeira, plantas tropicais entre outras fontes naturais foram retirados para atender aos interesses e projetos de crescimento econômico de Portugal.

Em 1808, Dom João VI fundou o Colégio Médico-Cirúrgico17, localizado na Bahia, em Salvador. A primeira cadeira de Medicina Clínica e Teórica foi criada em 1809, gerando a Carta de aprovados em Cirurgia, que ainda era inferior quando comparada as disciplinas de Medicina oferecidas em Portugal. Nesse sentido, criou-se um Plano de Estudos de Cirurgia, buscando dar respaldo aos cirurgiões, percebendo a Química Farmacêutica enquanto parte desse trajeto no final do primeiro ano. Além disso, "Quando o príncipe D. João se transferiu para o Brasil com toda a Corte [1808], os altos funcionários etc., transferiu também a Academia de Ensino da Marinha" (ALMEIDA, 2000 , p. 46). A referida academia foi instalada junto a um Mosteiro, o de São Bento, acompanhado de vários livros, instrumentos e plantas da Academia de Lisboa.

No Reinado de Dom João VI, houve a primeira iniciativa para a institucionalização das Ciências Naturais no Brasil, criando-se o "Laboratório de Química (...) em 1811" (ALMEIDA, 2000, p. 42). O interesse, atrelado com sua criação, está conectado à formalização de espaços voltados ao ensino da nova Ciência e para o treinamento de estudantes de Farmácia, aplicando-se os saberes da Química, recomendações que diziam respeito à Medicina, espaço privilegiado de produção de reagentes voltados à indústria, preparação de medicamentos, agricultura, metalúrgica e artes e ofícios. Antes disso, o Brasil era visto apenas como fonte de matéria-prima, a serviço de companhias de Comércio e Navegação. Depois, a vinda da corte para a antiga colônia exigiu a instalação, formalização e reconhecimento de novos espaços para a continuidade de seus projetos atrelados à Reforma Pombalina.

\footnotetext{
17 Segundo Lima (1969, p. 84), tratava-se de uma Faculdade de Medicina.
} 
Em 1810, Dom João VI fundou a Academia Militar Real do RJ. Da Academia Militar Real "se originou eventualmente a Escola Central, que deu origem à Escola Politécnica, unidade que hoje compõe a Universidade Federal do Rio de Janeiro" (FILGUEIRAS, 2015 , p. 199). Conforme os estudos de Almeida (2000, p. 47),

\begin{abstract}
o plano de estudos [da Academia Militar] era bem extenso e compreendia as Ciências Matemáticas, a Física, a Química e Metalurgia, a História Natural, Fortificação, Artilharia e Tática. A intenção de D. João VI era criar aí um viveiro não somente de oficiais de artilharia e engenharia, mas também de engenheiros, geógrafos e topógrafos, engenheiros de minas e serviços públicos, capazes de serem convocados para a direção dos trabalhos de mineração, portos, canais, fontes e calçadas. $\mathrm{O}$ curso era de sete anos e todos os livros escolares eram em francês.
\end{abstract}

As aulas de Química deram início na Academia Militar, em 23 de abril de 1811. Segundo Filgueiras (1990), com a instalação da Academia Real Militar o currículo de Engenharia adveio à Química, a Física, o Cálculo, a Mineralogia, a História Natural, etc. De acordo com Motoyama (2000), esse fato acarretou o crescimentode trabalhadores com formação especializada nas áreas que exigiam o ensinodirecionado às Ciências, ao passo que "a fundação da nova Academia Militar representou a institucionalização do ensino regular de ciências no Brasil, ou pelo menos seu planejamento" (FILGUEIRAS, 2015, p. 201).

Por conseguinte, Daniel Gardner produziu a primeira obra impressa do Brasil, intitulada Syllabus. Ao mesmo tempo em que conforme Filgueiras (2015), João Manso Pereira foi importante experimentalista e Químico que produziu livros no Brasil e também em Lisboa. Manso Pereira tinha uma familiaridade com a ciência corrente europeia da época.

Nesse contexto, os naturalistas, a par das atividades exercidas em Coimbra e no Brasil, foram, muitas vezes, secretários de Estado nos governos das colônias ou exerceram atividades de cunho administrativo. A Reforma de Coimbra, juntamente com a vinda da Família Real para o Brasil, trouxe fortes influências para o planejamento de um método educacional coletivo no território brasileiro, que seria parte indispensável e norteadora de uma nova forma de pensar a produção, a economia, o desenvolvimento tecnológico e do novo terreno. Nesse cenário, onde havia estratégias para alcançar êxito, houve a fundação de escolas, com forte relação no campo militar. Em 1814, inaugurouse a Biblioteca Pública, "criada principalmente com livros da Biblioteca Real do Palácio da Ajuda" (ALMEIDA, 2000, p. 47). No mês de Dezembro de 1815, Dom João VI intitulou - Brasil como Reino, para que fosse reconhecido pelas potências europeias. Tratava-se da declaração da independência, mesmo que Portugal e Brasil continuassem unidos.

Tomando todos esses acontecimentos como proveniência, uma forte influência do Iluminismo no Brasil está relacionada à afirmação do Padre (Pe.) Luiz Gonçalves dos Santos $^{18}$, referente às cadeiras de Ciências,

é com o coração cheio de alegria que eu felicito desde então minha pátria pela sorte
feliz que lhe prometo no futuro este estabelecimento do Instituto Acadêmico, o primeiro
a ser fundado na América Portuguesa, porque veremos sair daí hábeis professores
que, espalhando-se por este vasto reino, levarão a todas as províncias o bom gosto,
as Belas-artes e as Ciências e, de certa maneira, dissiparão a espessa nuvem de
ignorância e barbáries que, até o presente, obscureceu os horizontes destas belas
regiões. (ALMEIDA, 2000, p. 43 ).

Diante disso, em 1817, emergiu, na Bahia, a disciplina de Química, onde Sebastião Navarro de Andrade ${ }^{19}$ fora o responsável por ministrá-la. Segundo Ferraz (1997) as instruções desse curso demandavam dos professores ações teóricas e práticas, tornando ágeis os procedimentos químicos. Ao mesmo tempo em que, conforme Almeida (2000, p. 49), no mesmo ano (1817), "uma comissão de sábios austríacos e bávaros: Mikau,

\footnotetext{
${ }_{18}$ Foi palaciano na Corte de D. João VI, professor real interino de Filosofia Racional e Moral. Estudou Filosofia e também Teologia.

19 Atuou como secretário da Faculdade de Filosofia. Estudou Medicina, Filosofia e Matemática.
} 
Pohl, Spix, Martius e Raddi, acolhida regiamente por D. João VI, percorreu o Brasil e estudou as riquezas naturais."

No que diz respeito à preocupação de Dom João VI frente à instrução pública por meio da educação, Almeida (2000) afirma que, através do seu ministro de confiança Conde da Barca, Dom João VI buscou encontrar um indivíduo que apresentasse um plano de organização para a educação, através de um projeto. O projeto ordenado tinha como principal finalidade, "organizar a instrução pública [...] que reunisse todos os estabelecimentos entre si e os submetesse a um mesmo pensamento, o da unidade da nação" (ALMEIDA, 2000, p. 49).

No período de Dom João VI no Brasil, "um único pensamento tornou-se dominante: manter a autonomia deste vasto território e conservar a posse exclusiva para seus habitantes, a qualquer preço" (ALMEIDA, 2000, p. 55). As ações de Dom João VI ficaram restritas à Bahia e RJ, nesse sentido não se pode, nesse período, falar de iniciativas educacionais em todo território nacional. De qualquer modo, uma atenção para o período Colonial brasileiro permitiu elaborar uma espécie de linha pontilhada de proveniências que contingenciam a emergência de uma noção de Ensino de Química no período Imperial.

\title{
3 O PERÍODO IMPERIAL
}

\subsection{Dom Pedro I, a Independência do Brasil e o apagão científico}

Após a partida de seu pai (Dom João VI) para Portugal, o príncipe regente Pedro precisou enfrentar e resistir às diversas tentativas das Cortes $^{20}$, para que ele, assim como seu pai, retornasse até o solo português. Nesse movimento, aconteceram inúmeras revoltas no período regencial21. No dia 9 de Janeiro de 1822, Pedro decidiu ficar no Brasil, oficializando, por meio de sua fala, o ato conhecido como o 'dia do fico'. Após a ação de Pedro,

os atos do príncipe regente posteriores ao "fico" foram atos de ruptura. As tropas portuguesas que se recusaram a jurar fidelidade a Dom Pedro viram-se obrigadas a deixar o Rio de Janeiro. Esboçava-se a partir daí a criação de um exército brasileiro. Dom Pedro formou um novo ministério, composto de portugueses, mas cuja chefia coube a um brasileiro, José Bonifácio de Andrada e Silva². (FAUSTO, 2001, p. 73).

A formação do ministério de Dom Pedro contou com uma série de intervenções de José Bonifácio. Porém, é possível considerar que anterior às essas ações no Brasil, José Bonifácio realizou muitas outras em Coimbra. Uma atenção para essas iniciativas permite dizer que José Bonifácio,

\begin{abstract}
defendia idéias progressistas no campo social, como a gradativa extinção do tráfico de escravos e da escravidão, uma reforma agrária e a livre entrada de imigrantes no país. Politicamente, era um liberal conservador, adversário das "esfarrapadas bandeiras da suja e caótica democracia", como ele disse em certa ocasião. Considerava adequada para o Brasil a forma monárquica de governo, sustentada por uma representação dos cidadãos restrita às camadas dominantes e ilustradas. (FAUSTO, 2001, p. 73).
\end{abstract}

Sob esse aspecto, José Bonifácio, juntamente com a princesa Maria Leopoldina, foram os principais informantes de Dom Pedro I, quando o alertaram de que em Lisboa haviam determinado seu retorno até Portugal, acusando os seus ministros de traição à metrópole. Esse fato fora o estopim que,

\footnotetext{
${ }^{20}$ As Cortes formaram-se por meio de eleições, sendo elas constituídas praticamente por indivíduos nascidos no Brasil. Sobre os membros das Cortes, "Entre eles estavam alguns defensores radicais ou ex-radicais da independência, como Cipriano Barata (Bahia), Muniz Tavares (Pernambuco) e Antônio Carlos Ribeiro de Andrada (São Paulo), que haviam participado da Revolução de 1817" (FAUSTO, 2001, p. 72).

21 A Guerra dos Cabanos (Pernambuco) entre os anos de 1832 e 1835; Cabanagem (Pará) entre 1835 e 1840; Sabinada (Bahia) entre 1837 e 1838; Balaiada (Maranhão) entre 1838 e 1840; bem como a Revolução Farroupilha (Rio Grande do Sul) entre 1836 e 1845.

22 Esteve fortemente envolvido com pesquisas mineralógicas em Portugal. Formado em Filosofia e Direito, atuou como professor na Universidade de Coimbra (1801).
} 
alcançado a 7 de setembro de 1822, às margens do riacho Ipiranga [atualmente cidade de São Paulo], Dom Pedro proferiu o chamado grito do Ipiranga, formalizando a independência do Brasil. $\mathrm{A} 1^{\circ}$ de dezembro, com apenas 24 anos, o príncipe regente era coroado imperador, recebendo o título de Dom Pedro I. O Brasil se tornava independente, com manutenção da forma monárquica de governo. (FAUSTO, 2001, p. 74).

Dom Pedro I fundou a "Academia das Belas-artes, nas bases estabelecidas pelo Decreto Real de 25 de novembro de 1820" (ALMEIDA, 2000, p. 56). Suas ações na esfera científica, com ênfase nas Ciências Naturais/Química, foram muito discretas, quando comparadas às de seu pai, Dom João VI. Almeida (2000, p. 55-56) afirma que "este príncipe não foi indiferente à instrução de seu povo, como provam as medidas tomadas em seu reinado sobre o assunto. Mas faltou-lhe tempo e, no meio da efervescência política que dominava o país." Nesse sentido, o tempo de permanência de Dom Pedro I, como imperador, estagnou as discussões e iniciativas no campo das Ciências, permanecendo a Química em mesmo patamar que Dom João VI havia colocado. Mesmo com todo o aparelhamento científico trazido para o Brasil, a propósito da chegada da Família Real, só com Dom Pedro II a Química foi objeto de investimentos mais amplos. Aqui, a Química ultrapassa os interesses econômicos e políticos e passa a corresponder aos anseios de uma Química voltada para Educação.

\title{
3.2 Dom Pedro II: o incentivo a crescente dos conhecimentos científicos
}

Em decorrência das iniciativas primeiras da corte portuguesa, agora no solo da antiga colônia, os movimentos e operações para funcionamentos político-estratégicomilitares foram iniciados na então "sede" do país. Conforme Lima (1969, p. 73),

\begin{abstract}
a independência foi, pois, muito funcional para as elites comerciais portuguesas (digase inglesas) que se tinham radicado na colônia. "Tudo ficou mais fácil para o comércio internacional e nada mudava em termos de divisão do "bolo colonial": quem vinha usufruindo os lucros da ubérrima colônia continuou a fazê-lo, com a vantagem de, ainda por cima, poder legislar e independer das cortes lisboetas". Sem esta visão histórica é difícil compreender a divisão dos "dois brasis" que ainda perdura e o sentimento que o povo brasileiro tem de que o governo não é sua expressão política, mas a presença da Metrópole dentro da própria nação.
\end{abstract}

Compreender o período Imperial brasileiro exige uma reflexão sobre o primeiro imperador nascido no Brasil, Dom Pedro II, bem como sobre o último a sustentar a denominação de imperador. Filho de Dom Pedro I e de Leopoldina, Pedro II nasceu no dia nove de Dezembro de 1825. Em sete de Abril de 1831, Dom Pedro I ${ }^{23}$ abdicou de seu posto no Brasil, deixando José Bonifácio como tutor de Pedro II (o qual estava com apenas cinco anos de idade) até o ano de 1833. No dia 9 de abril de 1831, Dom Pedro II foi consagrado como Imperador do Brasil.

Nesse contexto, os anseios sociais já eram distintos dos anteriores, passando para ênfase legislativa e para esferas educacionais relacionadas à instrução primária. Seu período de governo durou entre 1831 e 1898 e, apenas nesse período, foram criados subsídios voltados ao Ensino de Química. Sua perspectiva era desenvolvimentista, objetivando instaurar, no Brasil, condições suficientes para o crescimento do Império. Por meio de várias viagens, conheceu personalidades científicas, que foram base para o seu interesse na pesquisa. "O imperador, é sabido, sempre estudou. De 1848 a 1850, as mudanças políticas do velho mundo tinham atraído sua atenção e muitas comparações deviam a se fazer no seu espírito clarividente e sábio" (ALMEIDA, 2000, p. 82).

Por meio das iniciativas e preocupações educacionais do Imperador Dom Pedro II, passou-se a dar mais atenção ao Ensino Primário no território brasileiro. Para Almeida (2000, p. 83, sic) "o Ministério, inspirado pelas idéias do soberano, obteve da Câmara

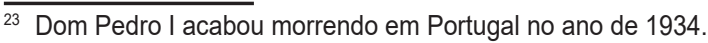


a votação da lei de 17 de setembro de 1851, que deu ao governo todo poder para reformar a organização da instrução primária."

No século XIX, o envolvimento de Dom Pedro II, juntamente com a preocupação com as Ciências Naturais foram intensificados, visto que não havia nenhuma perspectiva científica corrente no Brasil na época, a não ser tentativas singelas e sem repercussão, provocadas pelos Jesuítas da Companhia de Jesus no período Colonial. Dom Pedro II foi o principal representante dessa ação, o qual, além de dedicar seu tempo para estudar os horizontes da pesquisa, visitava as poucas escolas existentes da época, buscando conhecê-las e investigá-las em todas as suas esferas organizacionais.

Dom Pedro II sofreu influência daqueles que foram seus educadores, Bonifácio e Alexandre Vandelli, o que acarretou que ele se tornasse um indivíduo aplicado em estudar, pesquisar e discutir Química. Segundo Filgueiras (1988, v. 11), a casa de Dom Pedro II contava com laboratório de Química, onde ele praticava diversas experimentações, além de aprofundar seus estudos nas principais obras científicas da época.

Em 1837, por meio do Decreto $n^{0} 6.884$ de 02 de dezembro, emergiu a criação do Colégio Dom Pedro II. Nas palavras de Rosa e Tosta (2005), um dos objetivos da criação do referido Colégio esteve relacionado com o anseio de servir de modelo para as demais instituições de ensino no Brasil, além de estruturar o ensino em nível secundário. O currículo implantado no Colégio Dom Pedro II dispunha de disciplinas científicas, forte relação com os interesses de Dom Pedro II.

O referido Colégio passou por algumas reformulações curriculares, em virtude das modificações que as escolas francesas estavam fazendo na Europa, nesse sentido, somente em 1854 há uma alteração significativa no currículo, no que diz respeito à modificação daeducação secundária e primária. Aqui, a Química toma destaque, pelo artigo 79 do Decreto $n^{0} 1.331$,

Art. 79. Haverá no Collegio as seguintes cadeiras: [...] 2 de scienciasnaturaes, sendo huma de historia natural com as primeiras noções de zoologia, botanica, mineralogia e geologia, e outra de elementos de physica e chimica, comprehendendo somente os princípios geraes e os mais applicaveis aos usos da vida. (BRASIL, 1854, p. 45, sic.).

O Imperador também se preocupava com a educação das filhas, sendo a princesa Isabel a que mais teve afeição para os estudos científicos. A publicação de Filgueiras (2004) intitulada: "A Química na Educação da Princesa Isabel", é fiel em retratar os estudos de Isabel, bem como a insistência doimperador em torná-la uma apaixonada pela Química. Além do mais, Dom Pedro II tinha uma preocupação crescente em contribuir no alargamento cognitivo e intelectual da filha, visto que esta seria sua possível sucessora no trono.

No Brasil, os primeiros livros didáticos escritos foram introduzidos no Colégio Pedro II, desde 1858, por João Teixeira Martins. Logo, como é de conhecimento que apenas os mais ricos tinham acesso ao Colégio, constata-se que aelite intelectual brasileira foi impulsionada pela emergência do Colégio Pedro II. Durante toda sua vida, Dom Pedro II foi um apaixonado pelo saber científico e reuniu um considerável acervo de livros, documentos e relatórios sobre as Ciências Naturais oriundos de todas as partes do mundo. Ao fim da monarquia no Brasil, Dom Pedro II contribuiu significativamente para a nação, com seu acervo bibliográfico.

O estudo das Ciências durante século XVIII era considerado imprescindível para a constituição de um homem culto. Se, por um lado, existiam insistentes tentativas de instauração da Química enquanto disciplina no Brasil, por outro, as Ciências como um todo eram ditas como periféricas, isso porque estavam relacionadas à formação de trabalhadores. Segundo Lopes (1998), os saberes da Química nesse contexto estavam resumidos a leis que apresentassem relevância na prática. Conforme Chassot (1996), apenas em 1887 é que começaram a serem exigidos nas seleções de ingresso no Ensino Superior os saberes de Ciências Físicas e Naturais. 
Com a queda do Império no Brasil (1889), pode-se considerar que a forma do Ensino de Química, no final desse período, está totalmente relacionada com as ações provenientes de Dom Pedro II no território nacional. Enquanto isso, o mundo sofre o impacto da primeira Guerra Mundial (1914-1918), envolvendo o declínio da Europa e a ascensão dos Estados Unidos da América (EUA) enquanto potência internacional. A primeira grande Guerra Mundial é resultante da briga por território e pendor pelo interesse do desenvolvimento industrial da Química, tendo em vista que o Tratado de Versalhes, ao final da referida guerra, obriga a Alemanha a revelar os detalhes dos processos químicos das indústrias de corantes e medicamentos, além de fornecer material produzido nessas fábricas para os vencedores da disputa.

A primeira Guerra Mundial inaugura a 'Guerra Química', pois apresenta ao mundo a revolução tecnológica molecular, ou melhor, a aptidão de combinar e de romper moléculas. Disputas militares e comerciais convergem para o investimento em tecnologia de ponta, em virtude da crescente capitalista e da ocupação de territórios na Europa. Com Antoine Laurent Lavoisier (1743-1794) a Química começa a acentuar a habilidade de combinação dos elementos químicos. Com base nessa capacidade, a Química enquanto ciência começa a apresentar um potencial econômico e político, associado à descoberta da amônia por meio da combinação de Hidrogênio e Nitrogênio.

O desenvolvimento da pólvora negra (composta por Enxofre (10\%), Carbono $(15 \%)$ e Nitrato de potássio ${ }^{24}(75 \%)$ ) representa um importante desenvolvimento teórico/ científico na Química e também na Física, pois quando se queima a pólvora e esta entra em contato com o oxigênio, há a liberação de dióxido de carbono $\left(\mathrm{CO}_{2}\right)$, que se expandee é potente material energético (propelente sólido) para armas de fogo.

Os usos da pólvora, principalmente na dinamite, acarretou o aperfeiçoamento de uma tecnologia exclusiva da primeira Guerra Mundial, a nitroglicerina. A nitroglicerina, associada ao dióxido de silício em pó, serviu como base para a produção da dinamite, que acarretou ao seu idealizador Alfred Bernhard Nobel uma série de prêmios.

A tecnologia e o desenvolvimento da Química, durante a primeira Guerra Mundial, impulsiona, em larga escala, a estratégia de combate militar, em especial da artilharia, quando desenvolve a dinamite e gases de combate para serem utilizados em batalha. Aqui, as emergentes potências mundiais, representadas pelos impérios e Estados em formação e sua sede de conquistas e de delimitação de novos territórios, percebem o incrível poder de alcance da Química nas disputas. Ao término da primeira Guerra Mundial, entra em circulação todo um novo aparato científico-tecnológico no qual tem destaque a Química, principalmente no que diz respeito ao seu poder de produção de novas e definitivas armas, tais como a dinamite (nitroglicerina associada ao dióxido de silício em pó) e os gases tóxicos (gás mostarda).

As Ciências Naturais, a partir daí, de sua importância no campo científico-militar, promovem a divisão significativa das ciências em Física, Química e Biologia. Disciplinas que se tornam indispensáveis e decisivas em tempos de guerra e, paradoxalmente, renovam as promessas de paz.

\section{CONSIDERAÇÕES FINAIS}

O presente artigo permitiu apresentar o panorama genealógico das forças que concorreram para a emergência de um Ensino da Ciência Química ao final dos períodos Colonial e Imperial no Brasil. Com base nos interesses da Coroa, a Química passou a se mostrar de alta relevância, em virtude da sua utilidade para o Estado e a Segurança Nacional. Seu papel no isolamento e na purificação de compostos e substâncias passou a ser crucial às necessidades de desenvolvimento econômico e de expansão de impérios e nações por meio das invasões e navegações crescentes. As guerras e os avanços tecnológicos beneficiaram-se dos avanços da Química, principalmente nos campos da Medicina (por meio da manipulação dos fármacos), das armas (pólvora, combustíveis)

\footnotetext{
${ }^{24}$ Composto que é o agente oxidante, ou seja, que promove a liberação de oxigênio para o início da combustão do Enxofre e do Carbono.
} 
e, também, na exploração de minérios oriundos das colônias. É nesse sentido que a Ciência, principalmente a Química, torna-se alvo de interesses de Estado.

As iniciativas, tomadas aqui como proveniências, da Companhia de Jesus; de Pombal; de Dom João VI; Dom Pedro I e Dom Pedro II demonstram uma passagem para o entendimento da crescente necessidade do Ensino da Química, embora discreto, ao final do Império no Brasil. Com base nessas forças ocorre a transposição de uma Ciência de primeiro mundo para um país de terceiro mundo. Compulsoriamente uma Ciência imperialista adentra um contexto totalmente díspar ao que era desenvolvido na Europa da época. Conforme (BAZIN, 1977) é um tipo de formação do cientista que inaugura a dependência nos modelos educacionais europeus, adaptado, no Brasil, às necessidades das elites.

Atualmente, o que se pode considerar, no contexto do ensinar Química, é uma herança significante dos períodos Colonial e Imperial, em virtude da 'noção' da Ciência Natural ainda estar vinculada ao Brasil com status de país subdesenvolvido de terceiro mundo, além da dependência de modelos europeus (BAZIN, 1977), que ditam os 'nortes' das pesquisas, da formação dos cientistas, professores e, também, do Ensino em países cuja marca indelével de suas instituições é, ainda, a experiência de terem sido, nas idas de suas histórias, colônias de países europeus.

Uma genealogia das forças do Brasil Colonial e Imperial, que contingenciaram a emergência de uma noção de Ensino de Química, é estratégia que se materializa para pensar as condições de possibilidade que nos fez ser quem somos, melhor dizendo, tramas que se articulam para pensar o processo histórico a partir das descontinuidades.

\section{REFERÊNCIAS}

ALMEIDA, J. R. P. de. Instrução pública no Brasil (1500-1889). São Paulo: EDUC, 2000.

AZEVEDO, F. de. A cultura brasileira: introdução a cultura brasileira. 4. ed. Brasília: UNB, 1963.

BAZIN, M. J. O cientista como alfabetizador técnico. In: ANDERSON, S.; BAZIN, M. J. (Org.). Ciência e In/Dependência. Lisboa: Livros Horizonte, 1977. p. 94-98. v. 2.

BOERHAAVE, H. Traité de la virtudes médicamens. Paris: Jacques Chorizier, 1739.

BOTO, C. O curso de Medicina da Universidade pombalina: ciência e pedagogia no lluminismo português. In: FONSECA, T. N. L.(Org.). As Reformas Pombalinas no Brasil. Belo Horizonte: Fapemig; Mazza Edições, 2011. p. 11-48.

BRASIL. Decreto-Lei $n^{0} 1.331$, de 17 de fevereiro de 1854. Aprova o Regulamento para a reforma do ensino primário e secundário do Município da Côrte. Coleção de Leis do Império do Brasil, Rio de Janeiro, 17 fev. 1854. p. 45, v. 1, pt I. (Publicação Original).

. Lei n. 5.692, de 11 de agosto de 1971. Fixa Diretrizes e Bases para o ensino de $\overline{1^{\circ} \text { e } 2^{\circ}}$ graus, e dá outras providências. Diário Oficial da União, Brasília, DF, 12 ago. 1971. Disponível em: <http://www2.camara.leg.br/legin/fed/lei/1970-1979/lei-5692-11-agosto-1971357752-publicacaooriginal-1-pl.html>. Acesso em: 10 jan. 2019.

CORREAA, G. C. Educação, comunicação, anarquia: procedências da sociedade de controle no Brasil. São Paulo: Cortez, 2006.

O que é a escola? In: PEY, M. O. (Org.). Esboço para uma história da escola no Brasil. Rio de Janeiro: Achiamé, 2000. p. 51-84.

CHASSOT, Á. I. Uma história da educação química brasileira: sobre seu início discutível apenas a partir dos conquistadores. Episteme, v. 1, n. 2, p. 129-146, 1996. 
CROSLAND, M. Early Laboratories c.1600-c.1800 and the Location of Experimental Science. Annals of Science, v. 2, n. 62, p. 233-253, 2005.

FAUSTO, B. História concisa do Brasil. São Paulo: EDUSP, 2001.

FERRAZ, M. H. M. As ciências em Portugal e no Brasil (1772-1822): o texto conflituoso da química. São Paulo: EDUC, 1997.

FILGUEIRAS, C. A. L. A química na educação da Princesa Isabel. Revista Química Nova, v. 27, n. 2, p. 349-355, 2004.

D. Pedro II e a Química. Revista Química Nova, v. 11, n. 2, p. 210-214, 1988.

. Origens da Ciência no Brasil. Revista Química Nova, v. 13, n. 3, p. 222-229, 1990.

Origens da Química no Brasil. São Paulo: Unicamp, 2015.

Pioneiros da Ciência no Brasil. Revista Ciência Hoje, v. 8, p. 52-8, 1998.

FOUCAULT, M. Microfísica do poder. Rio de Janeiro: Graal, 1979.

FRANCA, L. O método pedagógico dos Jesuítas. Rio de Janeiro: Agir, 1952.

LIMA, L. de O. Estórias da educação no Brasil: de Pombal a Passarinho. Rio de Janeiro: Brasília, 1969.

LOPES, A. R. C. A disciplina Química: currículo, epistemologia e história. Episteme, v. 3, n. 5, p. 119-142, 1998.

MATHIAS, S. Evolução da química no Brasil. In: FERRI, M. G.; MOTOYAMA, S. História das ciências no Brasil. São Paulo: EDUSP, 1979. p. 93-110.

MAXWELL, K. Marquês de Pombal: paradoxo do lluminismo. Rio de Janeiro: Paz e Terra, 1996.

MOTOYAMA, S. 500 anos de Ciência e Tecnologia no Brasil. Revista Pesquisa FAPESP, n. 52, 2000. Edição especial.

NUNES, R. A. C. História da educação no Renascimento. São Paulo: EDUSP, 1980.

PIRES, C.; PEREIRA, G. Museu da Ciência da Universidade de Coimbra: valorização de um patrimônio científico secular. In: GRANATO, M.; LOURENÇO, M. (Org.). Coleções Cientificas Luso-brasileiras: patrimônio a ser descoberto. Rio de Janeiro: Museu de Astronomia e Ciência Afins - MAST/MCT, 2010. p.185-210.

ROSA, M. I. P.; TOSTA, A. H. O lugar da Química na escola: movimentos constitutivos da disciplina no cotidiano escolar. Revista Ciência \& Educação, v. 11, n. 2, p. 253-263, 2005.

SERRÃO, J. V. História das universidades. Porto: Lello \& Irmão Editores, 1983.

TELLES, V. C. S. S. Elementos da Química. Coimbra: Universidade de Coimbra, 1788. 